急性門脈遮断時の全身循環動態と肝および腎局所循環動態に

\title{
関する実験的研究
}

\author{
名古屋大学第 2 外科 \\ 星野 澄人 野浪 敏明 中尾 昭公 \\ 末永昌宏堀澤増雅高木 弘

\section{EXPERIMENTAL STUDY OF SYSTEMIC HEMODYNAMICS AND HEPATIC AND RENAL TISSUE BLOOD FLOW IN ACUTE POTAL VEIN OCCLUSION} \\ Sumito HOSHINO, Toshiaki NONAMI, Akimasa NAKAO, \\ Masahiro SUENAGA, Masumasa HORISAWA and Hiroshi TAKAGI \\ The Second Department of Surgery, Nagoya University School of Medicine
}

急性門脈遮断時の病態を明らかにする目的で全身循環動態をSwan-Ganz catheter を用いて, また 局所䛻環動態を電解式水素ガスクリアランス法により実験的に検討した。門脈遮断時には, 門脈系へ の血液の pooling に伴う hypovolemia とともに, 遮断時間が長くなるにしたがい心機能の㧕制が認め られた。また肝および腎組織血流量は急激に減少しつづけた。一方門脈体循環バイパス施行下門脈遮 断時には, 循環動態の変動は軽度であり, 肝組織血流量は遮断後早期には前値の50\%迄减少したが, その後は漸増傾向が認められた。 また腎組織血流量の減少は軽度であった。以上より門脈遮断時には 心機能抑制とともに重要葴器の局所循環障害もきたすが, 門脈体循環バイパス施行下に門脈遮断を施 行しても循環動態が良好に維持されるため, 重要藏器の局所循環も維持されると考えられた。

索引用語：急性門脈遮断, Swan-Ganz catheter, 電解式水素ガスクリアランス法, 肝㧍よび腎局所循環動態, 門脈体循環ハイハン

\section{I.はじめに}

急性門脈遮断時には早期より重篤なショック状態に 陥り, 実験動物は死亡する ${ }^{1) \sim 5)}$. そのショックの病態に は不明な点が多く, 旧来の外科手術に拈いては, 門脈 ばNoli me tangere”として危険視されてきた. しかし ながら最近の外科学の進歩に伴い, 肝胆荤外科領域に 扣いて積極的に門脈合併切除が行われるようになっ

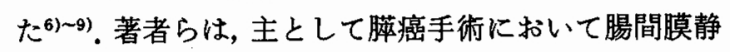
脈大腿静脈カテーテルバイパス法による門脈合併膵全 摘術10)を施行してきたが, 本法は門脈体循環バイパス 下に門脈遮断を行うものであり, 全身循環動態ならび に酸素需給動態に及ぽす影響も少なく安全な手術方法 であることを報告してきた ${ }^{11) 121}$. しかし門脈体循環バ

$<1985$ 年 7 月 10 日受理 >別刷請求先：星野 澄人

干466 名古屋市昭和区鶴舞町65 名古屋大学医学部 第 2 外科
イパスの準備なしに門脈合併切除が必要な場合や，不 虑の門脈損傷時などには一時的な門脈遮断が木可欠に なる、したがって急性門脈遮断時における病態の解明 は, 臨床的見地からも極めて重要である。

門脈は腸管からの drainage vein として大量の血液 を肝臓に流入させている。したがって門脈の遮断は, 腸管への急激な血液のうっ滞をきたして, 相対的循環 血液量の減少を招き，さらに遮断時期が延長すると心 機能の抑制が招来される13).このためこの病態は全身 諸藏器の局所循環に重大な影響を及ぼすと考えられ る、そこで著者らは，急性門脈遮断が肝および堅の局 所循環動態に及ぽす影響を明らかにし,さらに全身循 環動態の変化と対比して検討した。

\section{II. 研究方法}

1. 全身循環動態の測定

体重 $10 \mathrm{~kg}$ 前後の雑種成犬 10 頭を thiopental 静脈麻 
酔空気吸入自発呼吸下にて実験を施行した。外頝静脈 より Swan-Ganz catheter 7F (Edward)を㨀入し， 先端を肺動脈に留置して圧モニター（Roche 128）によ り肺動脈契入压（PWP， mmHg）を測定した。また Swan-Ganz catheterを熱稀釈心拍出量測定装置 (Model 9520A, Edward) に接続し, 対側頚静脈より 右房内に插入留置したカテーテルより， $0{ }^{\circ} \mathrm{C} ， 5 \%$ プ ドゥ糖 $5 \mathrm{ml}$ を注入し心拍出量 $\left(\mathrm{CO}, l \mathrm{~min}^{-1}\right)$ を測定し た. 同時に大腿動脈からカテーテルを插入し心拍数 (Pulse, $\mathrm{min}^{-1}$ ) と平均動脈圧 (mBP, mmHg) を测定 した。 なた腸間膜静脈より門脈にカテーテルを插入し て門脈王（PVP, mmHg）を測定した。これらの測定 值より心係数 $\left(\mathrm{CI}, l \cdot \mathrm{min}^{-1} \cdot \mathrm{kg}^{-1}\right)$, 左室 1 回仕事量 指数 (LVSWI， $\mathrm{gm} \cdot \mathrm{m} \cdot \mathrm{kg}^{-1}$ ) と全身末梢血管抵抗 （TPR, dyne ・ sec $\cdot \mathrm{cm}^{-5} \cdot \mathrm{kg}$ ) を求めた，尚心係数は 便宜上体重あたりの心拍出量として算出した.

2. 電解式水素ガスクリアランス法による肝拉よび 腎組織血流量の測定

体重 $10 \mathrm{~kg}$ 前後の雑種成犬10頭を用い, 同様の麻酔管 理下に開腹した. 肝中葉, 腎皮質に針型電極を刺入し， 2 チャンネル電解式組織血流計(RBF-2,バイオォディ カルサイェンス）に接続した，水素ガスの血流による クリアランスを片対数グラフ上にプロットし，半减時 間 $\left(\mathrm{T}^{1} / 2, \mathrm{~min}\right)$ を求め次式により組織血流量 (TBF, $\left.\mathrm{ml} \cdot \min ^{-1} \cdot 100 \mathrm{~g}^{-1}\right)$ を算出した ${ }^{14)}$.

$\mathrm{TBF}=69.3 / \mathrm{T}^{1} / 2 \mathrm{ml} \cdot \mathrm{min}^{-1} \cdot 100 \mathrm{~g}^{-1}$

血流測定終了後, 実験犬を塩化カリウムの投与によ り心停止させ，心停止状態において水素ガスの拡散に よる変化量（Fo）を求め, 実測值より Foを減じた值 を組織血流量とした。

3. 実験群の作成

1,2の実験犬の作成は, おの㧍の 5 頭ずつに肝門部 で門脈を露出し遮断した遮断群と, 門脈体循環バイパ ス下に門脈を遮断したバイパス群に分けた。門脈体循 環バイパスは，脾静脈と大腿静脈の間にアンスロン® バイパス用カテーテル12)15) (内径 $2.7 \mathrm{~mm}$, 他側内径 4 $\mathrm{mm}$, 長さ $40 \mathrm{~cm}$, 東レ) を用いた（図 1 ）. 両群とも全 身循環動態, 組織血流量の測定を門脈遮断前, 遮断後 5 分, 15 分, 30 分, 45 分, 60 分, 90 分に行った。なお 実験中は全例 $5 \%$ ブドウ糖 $10 \mathrm{ml} / \mathrm{kg} / \mathrm{h}$ にて輸液管理 を行った。

\section{III. 成 績}

1. 全身循環動態

$\mathrm{mBP}$ は遮断群では, 遮断後 5 分に急激に低下し, そ
図 1 実験犬のシェーマ

\section{実験 I 全身循環動態の測定}

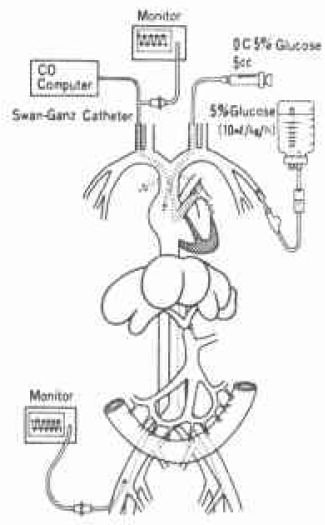

急性阴眽遮断犬

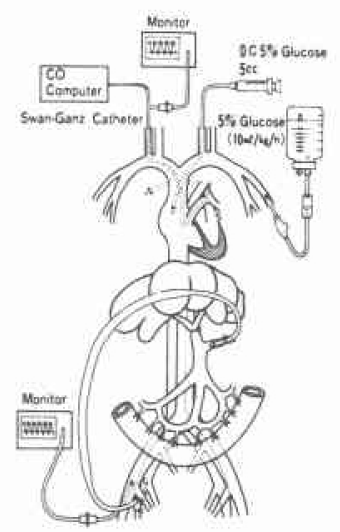

P睡体循環ハイパス犬

\section{実験 II肝および謷組織血流量の測定}

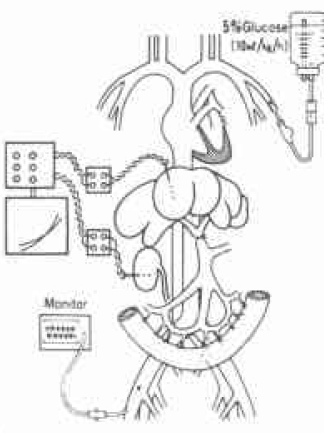

急性門腺䢥断犬

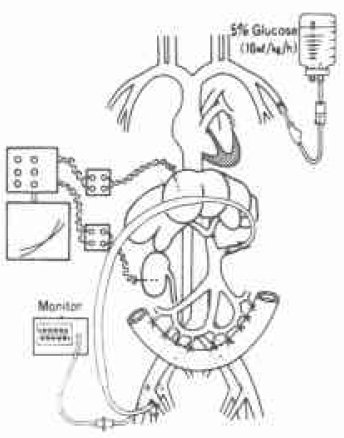

門脈体循理パイパス犬
の後も経時的に低下傾向が認められた。 パイパス群で は, 門脈遮断後軽度低下したものの，遮断群に比較し 有意に高值で経過した。TPR は遮断群では, 遮断後 5 分に急激な増加がみられた，その後一時的に低下した が, 遮断後45分以後再び増加した。一方バイパス群で の変化は軽度であり，遮断群に比較し有意に低值で経 過した (図 2 ). CI, LVSWI は遮断群では, 遮断後 5 分に急激に減少し遮断前值のほぼ20\%となった。その 後も経時的に減少傾向が認められた。バイパス群では 門脈遮断後軽度減少したものの, 遮断群に比較して有 意に高値で経過した（図 3)，PWP は遮断群では，遮 断後 5 分に急激に低下したが，その後は経時的に上昇 傾向がみられ, 遮断後 90 分には遮断後 5 分に比較し有 意に高值をとった。 PVPは遮断群では遮断後 5 分に $58 \pm 7.5 \mathrm{mmHg}$ と上昇したがその後は経時的に低下し 
図 2 遮断群, バイパス群の平均動脈压と全身末梢血 管抵抗の变動

$$
m B P
$$
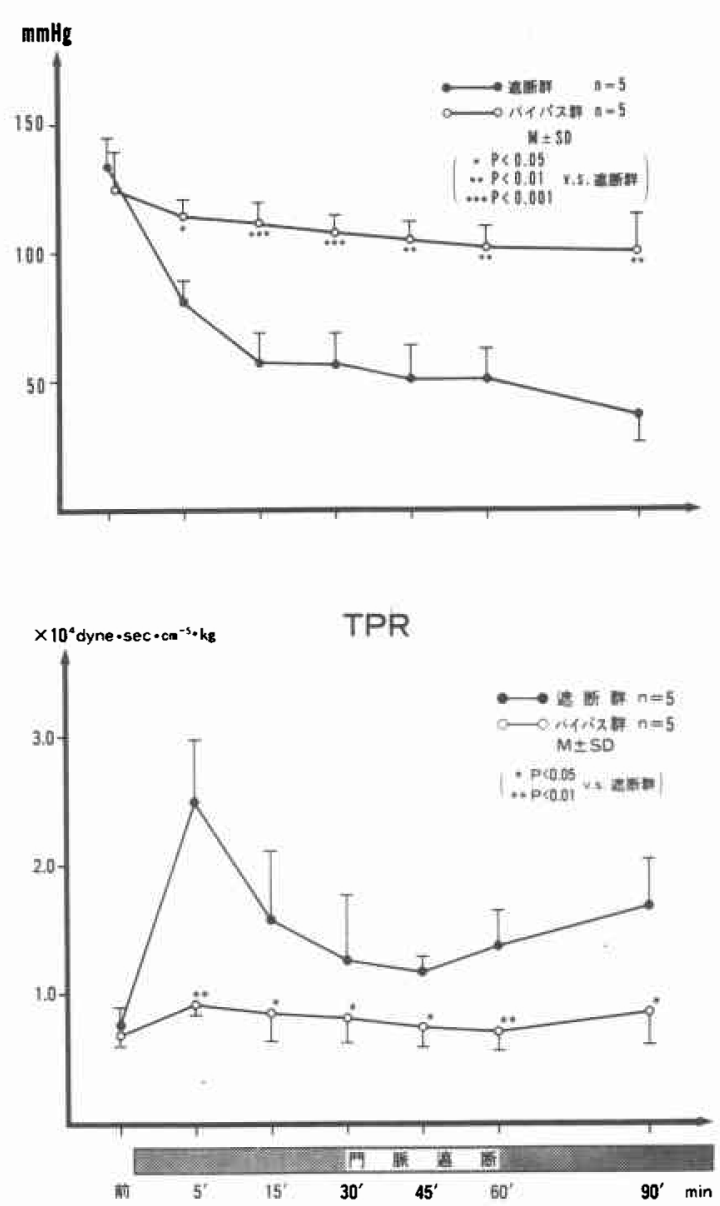

た。一方バイパス群では，門脈遮断後軽度上昇を認め たが，全経過を通じて遮断群に比較し有意に低值で経 過した（図 4 ).

2. 肝および堅の局所循環動態

門脈遮断前に括ける肝組織血流量 (HTBF) は, $47.2 \pm 15.9\left(\mathrm{M} \pm \mathrm{SD}, \mathrm{ml} \cdot \mathrm{min}^{-1} \cdot 100 \mathrm{~g}^{-1}\right)$ であり，腎

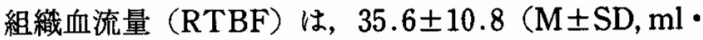
$\left.\mathrm{min}^{-1} \cdot 100 \mathrm{~g}^{-1}\right)$ であった. HTBF は遮断群では, 遮断 後 5 分に $25.8 \pm 12.8$ となり前値の約 $50 \%$ 迄減少し，そ の後も経時的に減少しつつけて遮断後 90 分では, $12.2 \pm 5.5$ となり前値の約 $25 \%$ 迄減少した.バイパス群 では遮断後 5 分に25.9土4.1であり遮断群と同様に急 激に減少した。しかしその後は経時的に増加傾向がみ られ，遮断後 90 分には31.3土11.5となり前值の約 $60 \%$
図 3 遮断群, バイパス群の心係数と左室 1 回仕事量 指数の変動
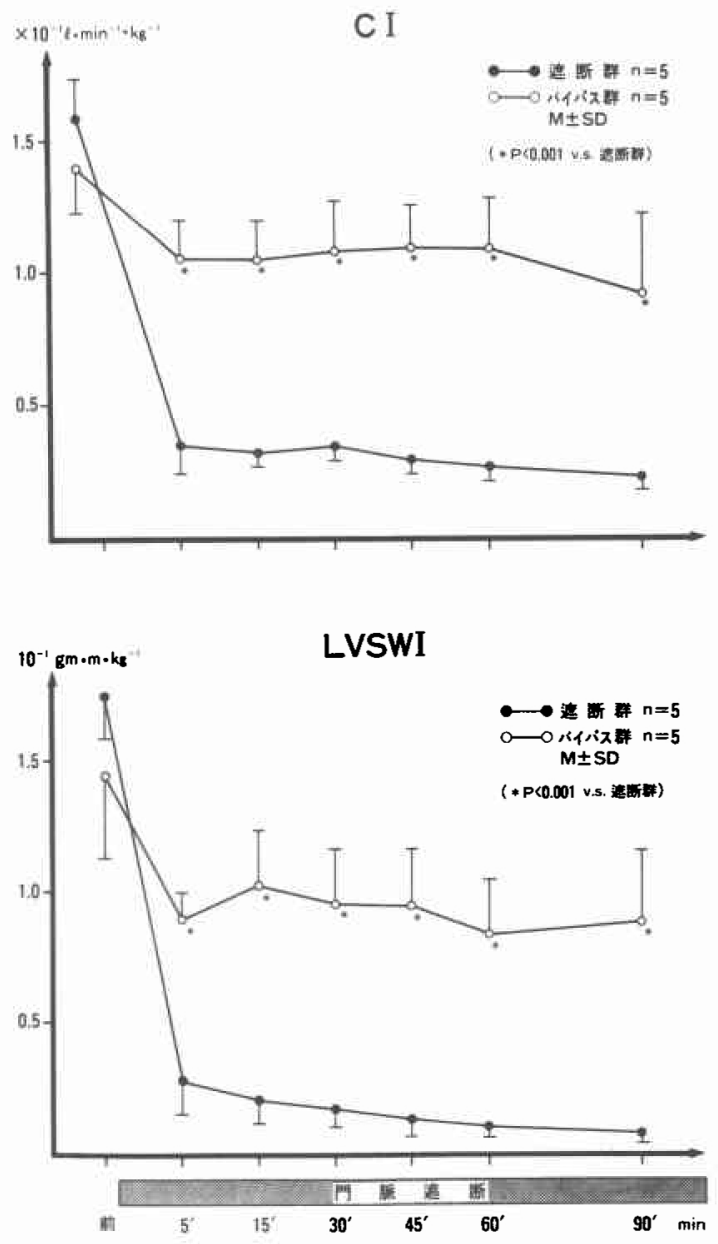

迄回復し, 遮断群に比較し有意に高値を示した（図 5 ). RTBF は遮断群では，遮断後 5 分に19.7士7.7 と前值 の約 $50 \%$ 迄减少し，その後も経時的に減少しつづけて

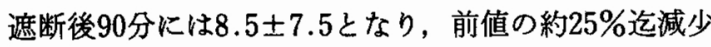

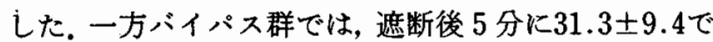
あり,遮断後90分には21.6士2.4となり前値の約 $60 \%$ 迄 減少が認められたが, 遮断群に比較し有意に高值で あった（図6）。

\section{IV. 考 案}

門脈は腹部内臓領域に竹ける drainage vein の本幹 として毎分500 1, 000 $\mathrm{ml}$ の酸素含量の高い血液を肝 葴に流入させている。したがって門脈の急性遮断は, 肝臟, 腹部内臓領域のみならず全身の循環動態に及ほ

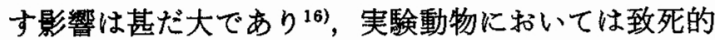


図 4 遮断群, バイパス群の肺動脈揳入王と門脈圧の 変動
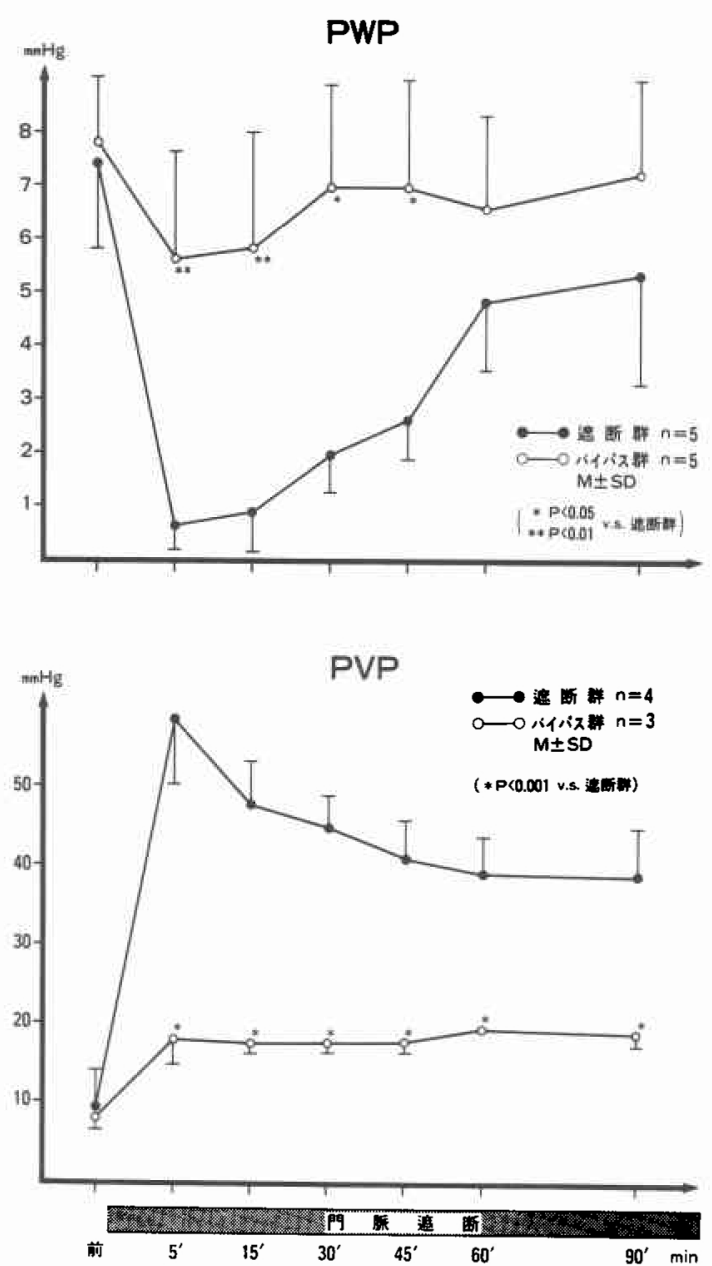

であるとされている。この病態を Bernard ${ }^{2}$ は，急激な 腸管へのうっ血に伴う hypovolemic shockであると し, Johnston ${ }^{17)}$ 実験犬に拈いては, 門脈遮断後, 有 効循環血液量の約 $60 \%$ が腸管にうっ滞するとしてい る. Beach ${ }^{18)}$ や Bergan ${ }^{19)}$ は, 門脈遮断後の急激な代謝 性変化がショックの大きな原因であるとした，また最

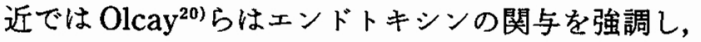
中尾 ${ }^{21)}$ は凝固線溶学的に門脈遮断後には早期に腸管に 不可逆珄の DIC を招来するとした. 著者らは全身血行 動態ならびに酸素需給動態から, 門脈遮断時の病態を 急性脱血実験と比較して, 遮断後早期のショックの病 態は急激な腸管へのうっ血に伴う hypovolemia であ るが，遮断時間が長くなるにしたがい経時的に心係数 の減少と肺動脈楔入匠の上昇を認めた（図 7)。した
図 5 遮断群，バイパス群の肝組織血流量の变動
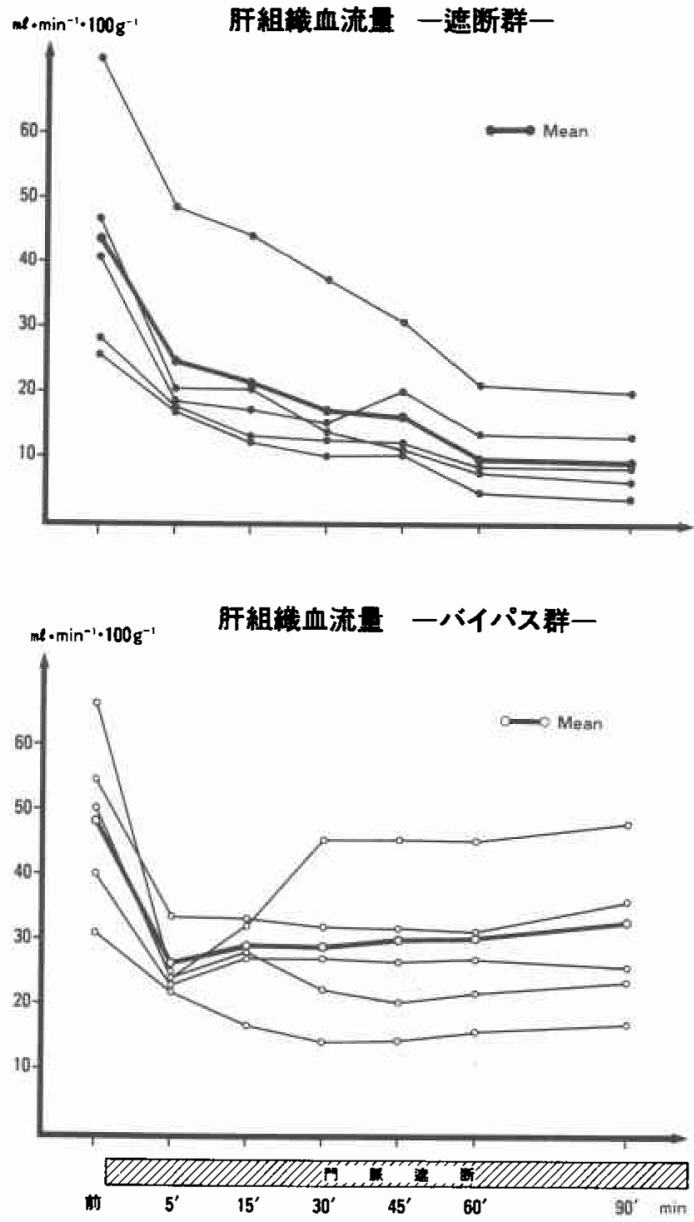

がって遮断時間の延長とともに心機能抑制が病態形成 の重要な因子となり，さらに酸素需給動態の破䋉が認 められることを明らかにした ${ }^{13)}$ 。この様に門脈遮断時 には全身の循環動態に与学影響は大きく，諸臓器の 局所㨁環に重大な影響を及ぼすと考えられるか゚，局所 循環から検討された報告はみられない。そこで著者ら は, 急性門脈遮断時の肝および腎組織血流量を測定し， 全身循環動態の变動と比較検討した。 また門脈体循環 バイパス下に門脈遮断を行い，全身循環を良好に維持 した場合の肝および腎局所循環動態の変動を検討し た.

各藏器の局所循環動態を明らかにするには水素ガス クリアランス法による組織血流量の測定が有力な一方 法である。水素ガスクリアランス法には吸入法と電解 法とがあるが, 最近では電解式水素がスクリアランス 
因 6 遮断群,バイパス群の腎組織血流量の変動

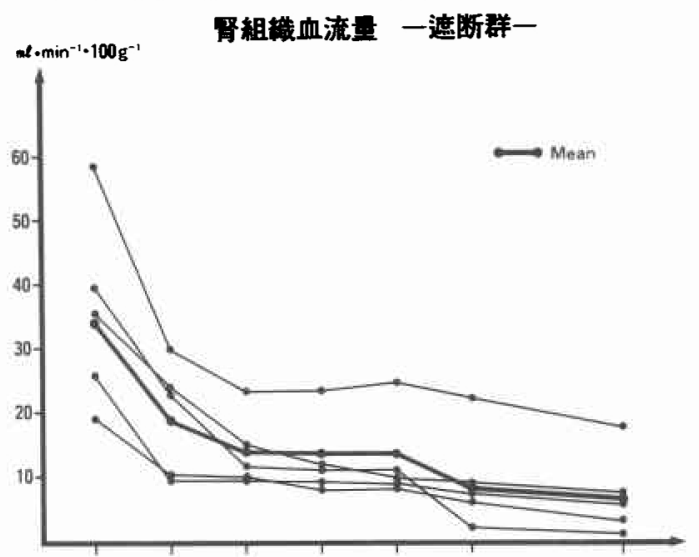

置組織血流量 一ハイイパス群一

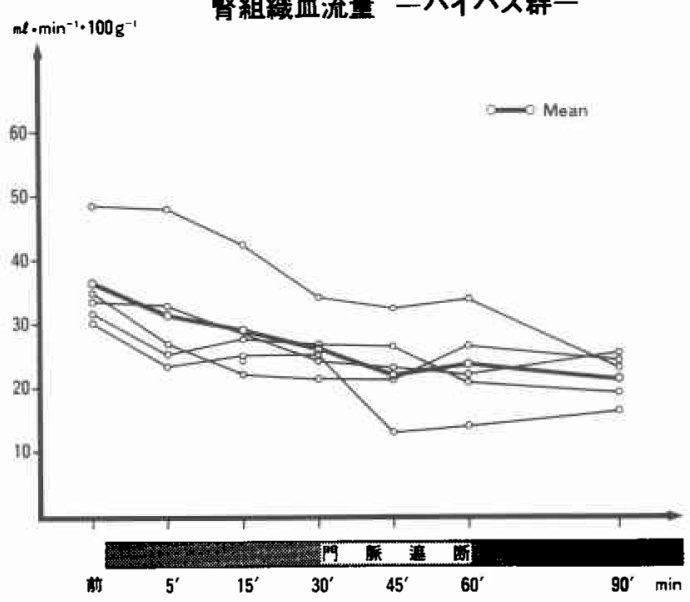

図 7 門脈遮断時, 急性脱血時の心係数と肺動脈揳入 圧の変動
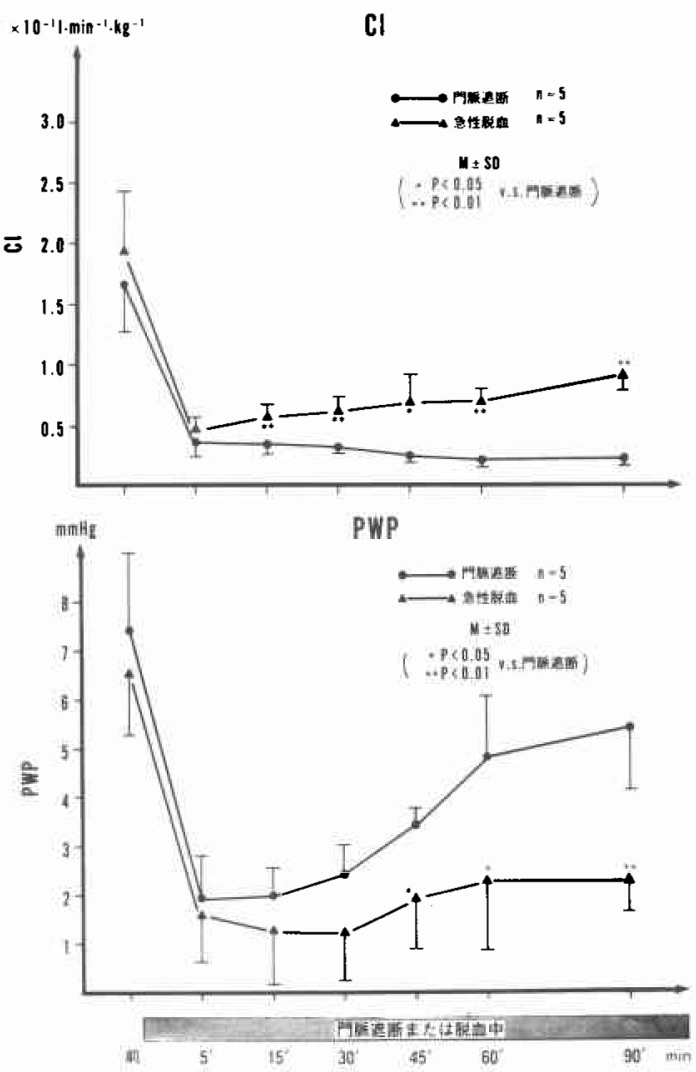

図 8 (左) 電解法と吸入法による肝組織血流量測定値の相関.（右）電解法と吸入法

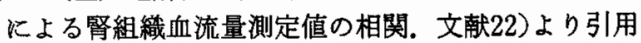
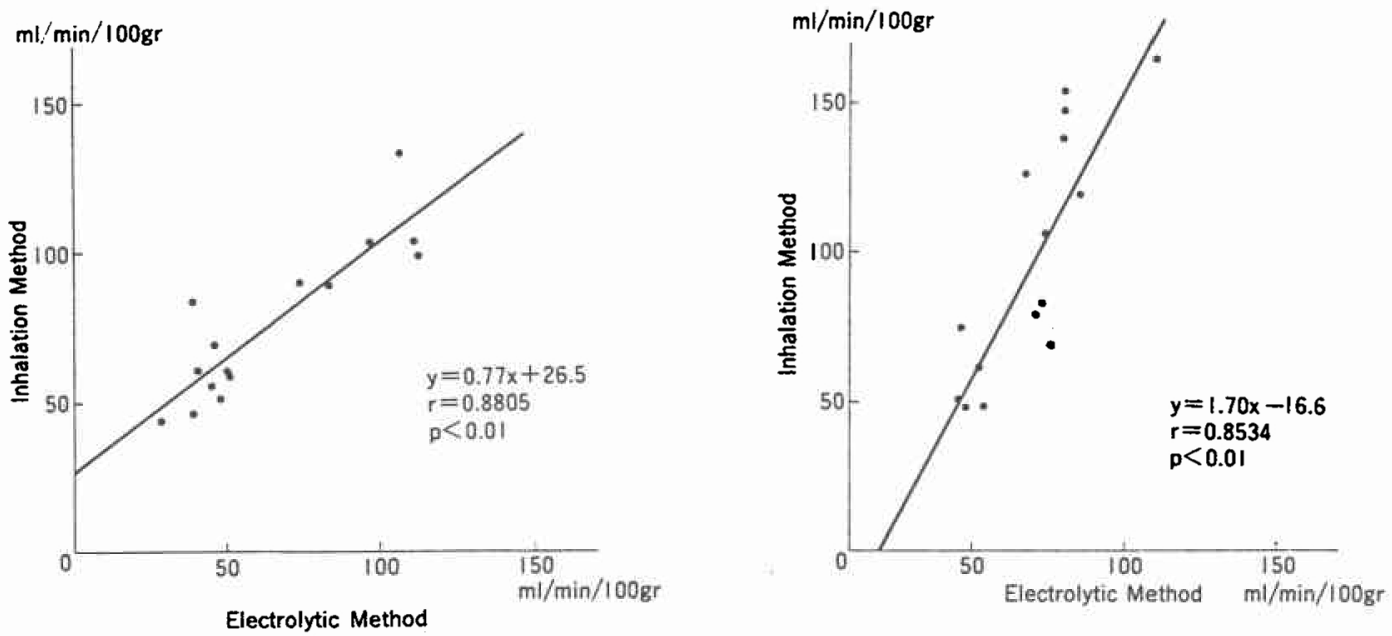
法が操作が簡便であり，水素ガスの吸入を必要としな いため安全性にも優れ, 最近では臨床においても使用 されつつある，著者らは，肝っよび腎の組織血流量を 電解法と吸入法で比較検討したが, 比較的良好な相関 が認められ ${ }^{22)}$, 電解法は局所循環動態の測定に信頼し うる方法と考㝋られる（図8).

門脈遮断時, 実験犬は遮断後 5 分に心係数. 左室 1 回仕事量指数は前值の約 $20 \%$ 迄急激に減少し，すみや かにショック状態に陥った。しかしながら肝および腎 組織血流量は, 遮断後 5 分には前値の約 $50 \%$ の減少に とどまり, 心係数の減少に比較し減少が軽度であった。 これは遮断後早期にさたす一過性の全身未梢血管抵抗 の急激な增加を考慮すると, 未梢循環の檥性のもとに 重要蔵器である肝および腎の局所循環が保持された結 果であると解される。しかし門脈遮断時には, 循環血 液量の減少に加えさらに心機能抑制をきたし, 心拍出 量は経時的に减少しつつうけるため末梢循環による代償 作用に破綻をきたし，肝扣よび腎組織血流量は経時的 に減少したと考えられる。一方六イ゚ス群の全身循環 動態の变動は, 遮断後早期には心係数, 左室 1 回仕事 量指数の減少は軽度であり, その後も汪とんど変化な く経過した。門脈遮断後早期の肝組織血流量の急激な 減少は, 肝への門脈流入血の途絶によるものと考兄ら れる，その後肝組織血流量は漸増するが，これは肝葴 は二重血行支配であることより，その後心係数が維持 されるため肝動脈血流量が代償性に増加したものと考 兄られる。腎組織血流量の変動は, 心係数の変動 とよく相関が認められた。

本研究の結果から, 門脈遮断時間が長くなれば心機 能抑制が認められ, さらに重要臓器の局所循環動態に も重大な影響を及ぼすことが明らかになった. Child ${ }^{23)}$ らはサルの門脈遮断実験にて，サル，ヒトなどの高等 動物は豊富な門脈と体循環系との間の側副血行路の発 達により, 急性門脈遮断に耐党らると考元た。しかし ながら荤頭部領域癌で一時的な門脈遮断が必要な場合 には, 通常その側副血行路は広範な後腹膜, 腸間膜, 肝十二指腸靯帯などの郭清により遮断されており,こ のような状況下での門脈遮断は本実験と同様の病態に なることが予想される。したがって一時的な門脈遮断 は短時間であれぱ生体に及汸す影響も少ないが，遮断 時間が長時間に及ぶ場合は心機能抑制と重要臓器の局 所循環障害をきたすため, 可能な限り門脈体循環バイ パス下に行うことがより良好な手術成績を期待しうる と考えられる.

\section{V. 結 語}

急性門脈遮断時の全身循環動態と肝および腎局所循 環動態の測定を行い以下の結果をえた。

1）門脈遮断時には,すみやかにショック状態に陥る が, 早期の病態は門脈系への血液の poolingによる hypovolemic shock であったが，肝抢よび腎組織血流 量はある程度維持された.

2. 門脈遮断時間が長くなるにしたがい心機能抑制 が認められ, 肝および腎組織血流量は減少しつづけた。

3）門脈体循環施行下に門脈遮断を行らと, 全身循環 動態に及ぼす影響は少なかった。肝組織血流量は, 遮 断後早期に急激に減少するがその後は漸増傾向を示し た。腎組織血流量の減少は軽度であった。

本研究の内容要旨は第24回日本消化器外科学会 (京都, 1984年 7 月）に执いて発表した。

\section{文 献}

1) Ore $M$ : Influence de I'obliteration de la Veine Porte sur la Sécrétion de la Bile et sur la Fonction Glycogenique du Fore. Compt rent Acad Sc 43 : 463-467, 1856

2) Bernard C: Cours de Médecine du College de France. Lecons sur le Diabète et la Glycogènese Animale, Paris, 1877, JB Baillière et Fils, p316: cited from Johnstone, FRC

3) Elman R, Cole WH: Hemorrhage and shock as cause of death following acute portal obstruction. Arch Surg 28:1166-1175, 1934

4) Schiff $M$ : Sur une nouvelle fonction du foie et des effects de la ligature de la veine porte. Arch Sc Physiques et Naturelles de Gnève 58 : 293-302, 1877

5) Boyce FF, Lampert R, Mcfetridge EM : Occulsion of the portal vein. J Lab Clin Med 20 : 935-943, 1935

6) Fortner JG, Kim DK, Cubilla $A$ et al: Regional pancreatectomy : en block pancreatic portal vein and lymphnode resection. Ann Surg $186: 42-50,1977$

7) 宫崎逸夫, 永川宅 和: 腪癌の拡大根治術. 胆と荤 $1: 441-450,1980$

8）鈴木 敞, 真辺忠夫, 谷 友彦注か：荻全摘術の妥 当性. 胆々膵 $2: 327-333,1981$

9）尾形佳郎, 大山廉平, 小林健三注：門脈合併切除 を伴 5 䐙十二指晹切除術. 外科診療 $20: 418$ $-428,1981$

10）中尾昭公, 堀澤增雅, 近藤達平注か：腸間膜静脈大 稂静脈カテーテルバイパス法による門脈合併膵全 摘術。手術 $37: 1-6,1983$

11）野浪敏明，中尾昭公，星野澄人活か：腸間膜静脈大 
眼静脈カテーテルパイパス法による門脈遮断時の 血行動態の検討. 日消外会誌 $17: 624-629,1984$

12) 中尾昭公, 野浪敏明, 原田明生录か：門脈バイパス 用カテーテル（フンスロン）の作制と臨床治験成 績. 臨外 $39: 383-389,1984$

13）星野澄人, 野浪敏明：急性門脈遮断時および解除 後の全身血行動態々酸素需給動態に関する実騟的 研究. 日外会誌 $86: 738-751,1985$

14) Aukland $K$, Boer BF, Berliner RW : Measurement of local blood flow with hydrogen gas Circ Res $14: 164-187,1964$

15) Mori $Y$, Nagaoka S, Masubuchi $Y$ et al : The effect of released heparin from the heparinized hydrophilic polymer (HRSD) on the process of thrombus formatron. Trans Am Soc Artif Intern Organs $24: 736-745,1978$

16）安藤久実, 藤井英樹, 星野澄人ほか：循環動態およ び腸管粘膜に対する門脈遮断の影響に関する実験 的研究. 日消外会誌 $15: 55-63,1982$

17) Johnstone FRC: Acute ligation of the portal vein. Surgery $41: 958-971,1957$

18) Beach PM, Torres E: Acute occlusion of the portal vein in dogs. Surg Gynecol Obstet 121 : $761-766,1965$

19) Bergan J, Teixeire E, Yu H et al: Hyperkalemia accompanying canine portal venous occlusion. Surgery $64: 629-633,1968$

20) Olcay I, Kitahama A, Robert HM et al: Reticuloendothelial dysfunction and eudotoxemia following portal vein occlusion. Surgery $75: 64-70,1974$

21）中尾昭公：急性門脈遮断時の凝固線溶系変化に関 する実験的研究。日外会誌 $84: 692-702,1983$

22）野浪敏明, 星野澄人, 近藤達平: 電解式水素ガスク リアランス法による肝および腎組織血流量の測 定. Cyto-protection \& Biology 2:17-25, 1985

23) Child CG, Roger FM, George RH et al : Sudden and complete occlusion of the portal vein in the macaca mulatta monkey. Ann Surg 132 : $475-495,1950$ 